\title{
SISTEM INFORMASI MANAJEMEN DALAM KETERBUKAAN \\ INFORMASI PUBLIK SEKOLAH
}

\author{
Naila Fadhilah \\ Universitas Negeri Padang \\ Indonesia \\ Email : naylaafd127@gmail.com
}

\begin{abstract}
ABSTRAK
Sistem informasi manejemen dalam era sekarang adalah salah satu pembuktian dilakukannya pengefektifan serta pengefisenan pekerjaan dalam segala bidang. Dengan teknologi segala hal yang perlu disampakan dapat dijumpai dan diperoleh melalui media saja. Dengan mencari kata kunci suatu instansi seperti sekolah akan dapat dijumpai apasaja yang berkaitan dengan sekolah tersebut persis seperti yang diupload. Dengan begini maka, sekolah dapat menginformasikan pada publik bagaimana gambaran sekolah tersebut dengan baik, dan data yang disampaikan ini tentu akan sangat udah diakses dan dapat diupdate sesering dan sebaik mungkin sesuai dengan perkembangan sekolah tersebut.
\end{abstract}

Kata Kunci : Sistem Informasi Manajemen, Sekolah, Informasi, Publik

PENDAHULUAN

Pada era globalisasi seperti saat ini segala sesuatu telah mengandalkan sesuatu yang berbau teknologi. Teknologi yang dimaksud sudah tergolong pada teknologi dengan kualitas yang tidak bisa diragukan lagi. Salah satu manfaat dan pengaplikasian dari teknologi yang dimaksud ini yaitu penggunaan dalam sistem informasi manajemen sekolah, yang mana dapat digunakan dalam keterbukaan informasi publik dari sekolah tersebut. 
Sistem informasi manajemen sangat banyak manfaat dan kegunaannya dalam bidang pendidikan, pada saat ini rata-rata setiap sekolah ataupun universitas telah menggunakan sistem informasi manajemen ini dalam jalannya kegitan mereka sehari-hari. Salah satu yang dilakukan oleh sekolah ataupun unversitas ini yaitu dengan menggunakan sistem informasi manajemen sebagai sarana untuk melakukan keterbukaan informasi instansi mereka kepada publik ataupun kepada orang-orang yang bersangkutan.

Dengan dilakukan pengaplikasian sistem informasi manajemen ini dalam pengelolaan informasi sekolah tentu akan berdampak juga pada peningkatan kualitas pembelajaran. Sebagaimana yang dikemukakan oleh (Dewi \& Sabandi, 2019) bahwa dengan ditingkatkannya kualitas pembelajaran dengan menggunakan ilmu pengetahuan sebagai dasarnya dan disertai teknologi yang semakin hari semakin berkembang ini maka kualitas pembelajaran akan dapat ditingkatkan dengan baik.

\section{KAJIAN TEORI DAN PEMBAHASAN}

A. Pengertian Sistem Informasi Manajemen

Sistem informasi manajemen adalah sistem yang gunanya untuk menghasilkan informasi yang berguna, tepat, aktual, terpercaya dan cepat yang mana informasi yang dihasilkan tersebut akan berguna sebagai bahan dasar untuk pedoman bagi seseorang dalam mengambil keputusan dan tentunya dapat membantu dalam proses kerja suatu instansi atau lembaga.

Jadi sistem informasi manajemen ini adalah salah satu bentuk pilihan yang digunakan sebagai media untuk mempermudah pekerjaan dan tentunya berguna untuk pemberian informasi yang baik dan tepat bagi yang bersangkutan.

B. Cakupan Penggunaan Sistem Informasi Manajemen

Yang menjadi cakupan dan ruang lingkup dari kegunaan sistem informasi manajemen dalm bidang pendidikan yakni sebagai berikut :

1. Berbagai setting yang dilakukan oleh pihak sekolah. Maksud dari setting yang dimakdukan ini yaitu pengelolaan pengaturan identitas sekolah, lalu program tahun ajaran baru, penginformasian kurikulum terbaru, penginputan database sekolah dan keperluan lainnya. 
2. Pengelolaan

bagian

kesiswaan. Yang termasuk

dalam pengelolaan kesiswaan

ini yaitu pengelolaan data diri siswa, beasiswa yang dapat diperoleh oleh siswa, catatan kedisiplinan siswa, catatan kesehatan siswa, prestasi yang diperoleh dan pengelolaan data-data alumni jika diperlukan suatu saat nanti.

3. Pengelolaan data akademik. Dalam data kaademik ada beberapa yang kelola yaitu berupa nilai siswa yang dikelola secara bertahap dan berkesinambungan, data kehadiran siswa, rencana pembelajaran yang akan dilakukan guru, pengelolaan mata pelajaran dan data prestasi yang diperoleh oleh siswa tersebut.

4. Pengelolaan guru dan para karyawan. Disini akan direkap baik bidata, keluarga, riwayathidup ataupun pendidikan dan lainnya mengenai guru dan karyawan yang bekerja disekolah tersebut.

\section{Pembahasan}

Sistem informasi manajemen dalam keterbukaan informasi publik sekolah telah dibahas bagian mana saja yang dimaksudkan. Dalam keterbukaan informasi akan suatu instansi tentu ada aturan informasi mana saja yang bisa untuk dibuka dan dibagikan dengan khalayak umum dan adapula informasi yang tabu untuk dibuka bagi masyarakat umum.

Dalam hal ini, sistem informasi manajemen sangat membantu sekolah dalam hal memberikan informasi siap saji bagi yang membutuhkan informasi tersebut. Sekolah dapat membuka informasi tentang instansinya dengan tujuan untuk meningkatkan minat orang tua untuk mempercayai anaknya disekolahkan disekolah tersebut. Dalam hal ini juga akan emnimbulkan kepercayaan pihak luar pada pihak dalam sekolah, yang mana pihak luar akan percaya bahwa sekolah tersebut menguak bagaimana jalannya kegiatan operasional, seluk beluk dan kegiatan sekolahnya tidak ada yang ditutupi.

Bentuk dari kegunaan sistem informasi manajemen dalam hal keterbukaan informasi publik ini ada beberapa yakni : 
1. Sekolah akan menambahkan apa saja kegiatan tetap yang dijadwalkan oleh pihak sekolah di portal sekolah. Hal ini akan dilihat oleh khalayak dan tentunya akan berfungsi sebagai media informasi.

2. Sekolah akan mencantumkan perkembangan siswa, baik itu prestasi yang diperoleh siswa didalam sekolah ataupun diluar sekolah. Ini bertujuan sebagai ajang promosi bagi sekolah bahwa sekolah bisa mendidik siswanya menjadi anak yang memiliki potensi. Selain itu, hal ini juga akan meningkatkan daya saing positif antar siswa bahwa dengan bersaing mereka akan bisa menjadi panutan bagi siswa yang lainnya.

3. Seanjutnya sekolah dapat mengpload segala hal yang berkaitan dengan warga sekolah. Baik itu data siapa saja guru, berapa jumlah guru, karyawan dan jumlah karyawan serta lainnya. Ini juga akan sangat berguna untuk update data yang akan memperlihatkan siapa saja yang ikut mendidik dan tergabung dalam hal belajar sang murid.
4. Selanjutnya yaitu sebagai ajang promosi atau perkenalan bagi sekolah itu sendiri. Sekolah akan membuat dengan jelas biodata sekolahnya, alamat sekolah itu berada, jumlah siswa, prestasi yang dicapai siswa selama bersekolah disekolah tersebut termasuk visi, misi, tujuan dan target sekolah serta banyak hal lainnya.

Jadi penjelasan diatas adalah beberapa keguanaan atau fungsii dari sistem informasi manajemen yang digunakan disekolah-sekolah sebagai media untuk keterbukaan informasi publiknya. Sekolah pada saat sekarang ini telah dibimbing untuk gencar-genar melakukan hal ini. Salah satunya sekolah telah mengupload data sekolahnya dalam portal dapodik yang mana akan sangat memudahkan sekolah ataupun dinas pendidikan daerah dan pusat dalam pendataan sekolah tersebut, karena hanya dengan mengupload yang dapat dilakukan pihak sekolah dimana sajadan dibekali peralatan komputer dan internet maka tidak diperlukan lagi pengantaran data kepusat yang dilakukan secara manual. 


\section{KESIMPULAN}

Jadi sistem informasi manajemen adalah suatu sistem ataupun portal yang dapat digunakan sebagai media untuk mengefisienkan kera suatu instansi ataupun organisasi. Sistem informasi manajemen akan memberikan manfaat yang sangat dirasakan oleh instansi itu sendiri, dimana dengan adanya SIM maka sekolah dapat meringankan tugas beberapa pihak dan memuahkan dalam hal pemberian informasi dan jalannya kegiatan belajar mengajar.

Dalam fungsinya tersebut, sekolah dapat menggunakan sistem informasi manajemen salah satunya yaitu dalam keterbukaan informasi publiknya. Hal ini dimaksudkan bahwa sekolah membuka informasi yang dirasanya perlu disampaikan kepada yang memerlukan dan dapat diakses dengan cepat dan terbukaa pada siapun yang menginginkan informasi tersebut.

Salah satu bentuk dari pemanfaatan ini yaitu dengan dipostingnya bidata sekolah, keadaan siswa selama bersekolah yang diantaranya prestasi yang diraih, peningkatan akademik siswa, jumlah siswa, motto sekolah, visi, misi dan lain sebagainya yang masih pantas untuk dibagikan bagia khalayak.

\section{DAFTAR PUSTAKA}

Natakusuma, E.K. 2003. "Perkembangan Teknologi Informasi di Indonesia”. Bandung : Pusat Penelitian Informatika.

Usman, Husaini. 2008. Manajemen Teori, Praktik, dan Riset Pendidikan. Jakarta : PT. Bumi Aksara.

Dewi, A., \& Sabandi, A. (2019). PERSEPSI GURU DALAM MENINGKATKAN MUTU PENDIDIKAN BERBASIS SISTEM INFORMASI MANAJEMEN DI SEKOLAH DASAR NEGERI 08 BATANG ANAI. Jurnal Bahana Manajemen Pendidikan, 8, 125-131. Retrieved from http://103.216.87.80/index.php/bahan a/article/view/105303/pdf 